THE POLITICS OF DISCOURSE:

THE STANDARD LANGUAGE QUESTION IN

BRITISH CULTURAL DEBATES 


\section{THE POLITICS OF DISCOURSE: \\ THE STANDARD LANGUAGE QUESTION IN BRITISH CULTURAL DEBATES}

Tony Crowley

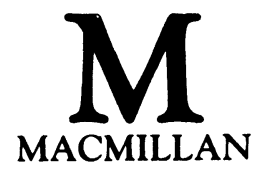


All rights reserved. No reproduction, copy or transmission of this publication may be made without written permission.

No paragraph of this publication may be reproduced, copied or transmitted save with written permission or in accordance with the provisions of the Copyright Act 1956 (as amended), or under the terms of any licence permitting limited copying issued by the Copyright Licensing Agency, 33-4 Alfred Place, London WC1E 7DP.

Any person who does any unauthorised act in relation to this publication may be liable to criminal prosecution and civil claims for damages.

First published 1989

Published by

MACMILLAN EDUCATION LTD

Houndmills, Basingstoke, Hampshire RG21 2XS

and London

Companies and representatives

throughout the world

Typeset by Wessex Typesetters

(Division of The Eastern Press Ltd)

Frome, Somerset

British Library Cataloguing in Publication Data

Crowley, Tony

The politics of discourse: the standard language question

in British cultural debates

1. English language. Historical linguistics

I. Title

420

ISBN 978-0-333-45471-8

ISBN 978-1-349-19958-7 (eBook)

DOI 10.1007/978-1-349-19958-7 


\section{Contents}

Preface $\quad$ ix

Acknowledgement $\quad$ x

Introduction $\quad 1$

1 A History of 'The History of the Language' 13

Introduction $\quad 13$

The appearance of historicity 14

History and language in Britain 20

Appeals for 'the history of the language' 27

The birth of 'the history of the language' 31

The study of language and British history 39

Conclusion $\quad 49$

2 Archibishop Trench's Theory of Language: the Tractatus Theologico-Politicus 51

Introduction 51

Language as material history $\quad 54$

The historical theology of language $\quad 59$

Language: the political unconscious $\quad 66$

Language and social unity $\quad 74$

Trench and the appeal for English studies 83

Conclusion $\quad 89$

3 The Standard Language: the Literary Language 91

Introduction $\quad 91$

Maintaining standards 93

Finding a language: where to look and what to
look for

The standard language: the uniform language? $\quad 99$

The standard language: the central form 104

The $O E D$ : the theoretical source of the standard literary language $\quad 107$

Conclusion $\quad 124$ 
vi GONTENTS

4 The Standard Language: the Language of the Literate 125

Another standard 125

'The higher instrument': a standard for speech $\quad 129$

The lower instruments of speech: the spoken dialects 138

The standard spoken language: whose language? $\quad 145$

Sub-standard English: the fatal letters 151

Conclusion $\quad 162$

5 Theorising the Standard: Jones and Wyld 164

Introduction 164

Theorising the spoken standard: Daniel Jones 165

Henry Wyld 174

Further theoretical developments $\quad 188$

The best English: the superiority of Received

Standard English 194

Conclusion 204

6 Language Against Modernity 207

Language and class $\quad 207$

The articulate and the barbarians 214

Language, nation and citizenship 222

Language and education 234

Conclusion: language against modernity 250

7 Conclusion: Past and Present 258

Introduction 258

Mellifluous rhetoric: the language trap $\quad 259$

Returning to Victorian values 269

The politics of discourse $\quad 272$

Notes $\quad 275$

Bibliography of Works Consulted 279

Index 299 
For My Father

Cornelius Crowley

Sí teanga na muintire a shlánós an mhuintir 


\section{Preface}

If I were to thank all those who have helped me to write this book it is possible that this preface would be longer than the main body of the text. So I shall have to apologise in advance to anyone I leave out. My first thanks are to Professor Roy Harris of the University of Oxford who supervised my doctorate on a related topic; and to Alan Ward and Raymond Williams who examined it. Thanks of this order are also due to Dennis Horgan who helped me start this project, and to Kate Belsey, Terry Eagleton, Cathy Fuller and Andrew Thacker who read and gave me help with later work. My colleagues and students at the universities of Oxford and Southampton have my gratitude for putting up with me and for giving me the intellectual space and time in which to work. Special thanks in this respect to my special option group of 1986-7. And my very, very special thanks to the secretaries at the Department of English in Southampton: Sheila James, Jill Bennett, and in particular Norma Martin who provided such cheerful and indispensable help.

My thanks are also due to all those who friendship and good advice made it worth undertaking this project: Sue Forber, who gave me great friendship, support and encouragement in times of doubt; Isobel Armstrong, Debbie Cameron and Edmund Papst who often, in different ways, made me think things through again when I wrongly thought that I had proved my point; Courtney Greenaway and Kadiatu Kanneh who have made me think in new and better ways; Tom Mulhearn who has long given me the benefit of his friendship and logical skills. Also Angela Poingdestre, Steve Sheedy, and all the Prangleys: Clare, Paul (the boss), Ged, Ant, John, and most of all Kate, who have long supported me.

Perhaps my deepest debt can be acknowledged last. To my brother and sisters, Nicky, Collette, Terry and Jacky, and my father, Cornelius Crowley, I offer my thanks and love. 


\section{Acknowledgement}

I would like to thank Oxford University Press for their permission to include the diagram from the 'General Explanations' in volume 1 of The Oxford English Dictionary, ed. J.A.H. Murray.

T.G. 